\title{
Revisiting Mary Daly: Towards a quadripartite theological and philosophical paradigm
}

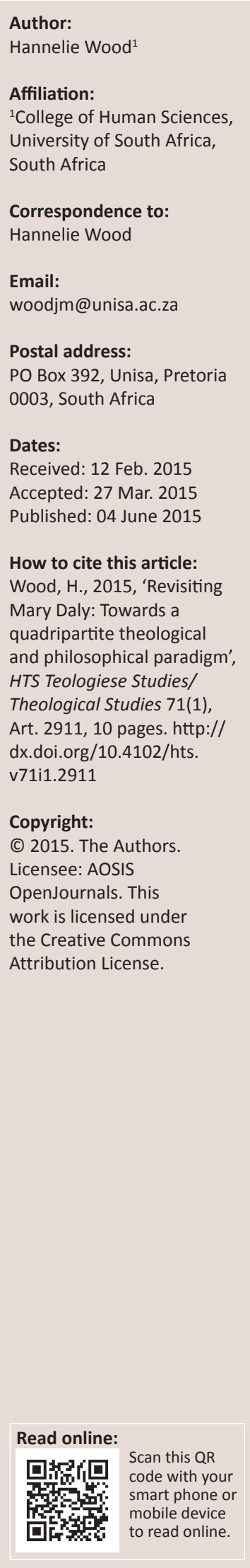

I was a tenderfoot in feminist discourse when I started my research on patriarchy, feminism, and Mary Daly. In my thesis, one aspect I engaged was Daly's battle with gender issues in Christian theology. From the beginning I was troubled by Mary Daly's views on God, men, and women in her discourse on Christianity. Daly undoubtedly contributed to the discussion on gender issues in the Christian faith, but her focus on androcentrism and her interpretations of Scripture led her to abandon the Christian faith. Mary Daly has written extensively on patriarchy as it is found in religion - particularly in the Christian faith - and how it filters through society. In her critique of patriarchy she set her course to dismantle the facade of a patriarchal and misogynistic God as the root of patriarchy. Daly did not see any positive qualities of the Christian faith and completely rejected other interpretations of a God whose person embraces both male and female qualities. Against this background I will evaluate Daly's post-Christian feminist theological and philosophical paradigm. I propose that Daly has a quadripartite theological and philosophical paradigm wherein there are four main players. The 'Who is who' in Daly's quadripartite patriarchal theological and philosophical paradigm are the patriarchal male, the patriarchal female, the patriarchal God and the biophilic woman.

\section{Introduction}

Durham, a psychologist, in her doctoral discourse of Daly's patriarchal religion, makes an attention-grabbing observation about Daly's having a tripartite psychological paradigm. Durham (1997) refers to these three paradigms as the sadistic patriarchal male, the masochistic patriarchal female, and the biophilic woman. In my thesis, one aspect I engaged was Daly's battle with gender issues in Christian theology. I contended that Daly has a quadripartite theological and philosophical paradigm. The four main players in Daly's patriarchal religion and philosophical paradigm are the patriarchal male, the patriarchal female, the patriarchal God, and the biophilic women. In this article I will mainly concentrate on Daly's works and my DTh thesis (Wood 2013). I am committed to the inerrancy, inspiration, and the final authority of Scripture, but also acknowledge the importance of the historical-cultural background of the Bible. I condemn the use of the Bible to justify and/or inflict any injustice upon any human being, whether this takes the form of patriarchy, feminism, slavery, or racism. Let us explicate these role players.

\section{An overview of Daly's patriarchal male}

The patriarchal males referred to by Daly are religious clerical males (representing the church), and males in other social professions she encountered. Daly applied her thoughts on the patriarchal male throughout her books and it is clearly fiercely anti-male. Daly (1978) states:

\footnotetext{
... that males and males only are the originators, planners, controllers, and legitimators of patriarchy. Patriarchy is the homeland of males; it is Father Land; and men are its agents. ... we live in a profoundly anti-female society, a misogynistic 'civilization' in which men collectively victimize women, attacking us as personifications of their own paranoid fears, as The Enemy. Within this society it is men who rape, who sap women's energy, who deny women economic and political powers. (pp. 28-29)
}

To Daly the Christian tradition of God as Father, and the maleness of God and Christ legitimise and reinforce male power in society - something she believed women could and should not identify with. Daly argued that patriarchy, with its misogynistic agenda, uses theology, metaphysics and language to victimise women in every sphere of their lives.

Daly's hermeneutical approach lay in her belief that men used their imagination to construct God as male, and in so doing provided themselves with the basis of patriarchy and the consequential oppression of women (Bickley 2011:42). Daly saw women as having been subjected to 'sex role socialization', and she believed that patriarchal male paradigms dominated women's experience (Bickley 2011:4241). 
Daly presents all males as patriarchs and as the vehicle for the church's patriarchal teachings on the nature of women and the nature of God. Daly claims that women are kept in place by church symbols imbedded in the church's masochistic response to women with its eternal feminine-divine plan but that women are to remain submissive, meek, and obedient (Daly 1975:54). The church is guilty because it serves a patriarchal society and applies double moral standards to women. On the one hand, the church wants to keep patrimony intact, but on the other hand, it dichotomises women as either virgins or whores (prostitution) as a tool to keep patriarchy intact (Daly 1975:63). Daly argues that the teachings of the patriarchal clergy and Christianity generally encourage selfhate and feelings of inferiority in women by their portrayal of women as evil and men as innocent (Daly 1987:46).

Misogynist churchmen such as Jerome, Augustine, Clement of Alexandria, Bonaventure, and Aquinas, to name a few, perpetuated the views of women as sinful and inferior and thus contributed to women's masochism (Daly 1975:62, 76-88). For Daly, these male patriarchs projected their own sexual weaknesses on women. This was because male patriarchs were 'hyper-susceptible to sexual stimulation and suggestion were transferred to the "other" the "guilty" sex' (Daly 1975:89). The views of the patriarchal male in which they regarded Mary and all women as symbolic objects are 'fundamentally hostile and egoistic' (Daly 1985:81-82) and the doctrine of the Assumption and Immaculate Conception are patriarchal males' attempts to placate women whilst keeping them suppressed (Daly 1985:87-88).

There is no question that Daly hated men. In an interview with Bridle (1999), Daly (1985) states:

\begin{abstract}
As I wrote in Gyn/Ecology: All patriarchal religions are patriarchal - right? They take different forms. What would I think? There is nothing to think about. It has taken another form seductive, probably, because Christianity is so overtly warlike and abusive. And furthermore, I don't know what enlightenment means. It is not a word that's in my vocabulary. This is like a Christian woman being upset over something that Paul said, instead of seeing that of course he's an asshole. He's one more very macho asshole described as a saint and as enlightened, and once you get over that, you get over it. You see it for what it is and you don't worry about why he would say such a thing. Of course he would say such a thing. That's what he is. It's really extremely simple. Stop wrestling with it; it's not interesting. Get out of it. That would be my approach to it. Misogynists! Hateful! All of them! I studied them. And finally I just didn't try to reason with it anymore. Boston College was most enlightening to me. The experience of being fired for writing 'The Church and the Second Sex' introduced me to the idea that it's not going to change. That's the way it is - leave it. (p. 11)
\end{abstract}

In the same interview, Daly made it clear that she did not think about men and when pushed to answer a question about the differences between women and men Daly (in Bridle 1999) categorically states:

You know, I don't mean to be unpleasant, but we're coming from different worlds. I was trained in that world of thinking, a certain christian or Western philosophical way, but I don't want to be drawn into talking that way because I don't relate to it and it irritates me. (p. 33)

In addition, when asked whether her idea of an idyllic prehistoric culture could be interpreted as romanticisation, Daly (in Bridle 1999) responds:

... we live in hell. This is called hell. H-E-L-L - patriarchy. ... I think the question comes from not looking deeply enough at the horror of phallocracy, penocracy, jockocracy, cococracy, call it whatever - patriarchy. (p. 22)

Daly's perceived mental, spiritual, and physical horror which women experience is an unbearable situation for her, and therefore she believed that women need a new kind of dream - the dream of escaping from the patriarchal male. Daly also emphasised her belief that in order for women, and other forms of life, to survive, the earth needs to be decontaminated; her solution to this was a drastic reduction of the male population.

In Gyn/Ecology, Daly takes Christian virtues and turns them into 'the deadly sins of the Paternal Parasites' who hide their 'vampirizing of female energy by deceptive posturing in the form of processions'. Paternal parasites is a term that she coined to name the deceptions of the fathers as 'demons wearing multiple forms of masks'. The eight deadly sins of male patriarchy are processions, professions, possession, aggression, obsession, assimilation, elimination, and fragmentation (Daly 1978:30).

Daly blamed men for not recognising that their misogynistic and evil patriarchal religion that they portrayed as the will of God had actually harmed women so deeply. In her journey of be-ing, Daly also started to distance herself from those women who did not share her radical women's liberation vision. The following portray her views on the patriarchal female.

\section{An overview of Daly's patriarchal female}

Throughout Daly's works, it is clear that she favoured women, but one is surprised when Daly showed some bias against certain women, especially those who did not share her radical women's liberation vision. In Gyn/Ecology, Daly states that she finds it to be a delicate choice between the two pronouns we and they when she is referring to women. Daly came to realise that she was unable to identify with certain women, even those who described themselves as feminists, and therefore she felt that they did not warrant the pronoun we (Daly 1978:25). Daly (1978) states:

... as the extent of the risk of radical feminism becomes more evident, it becomes clear that there are women, including some who would describe themselves as 'feminists', with whom I do not feel enough identification to warrant the pronoun we. (p. 25)

Daly believed that her use of the label 'anti-male' has intimidated certain women who then felt a false need to make distinctions such as 'I am anti-patriarchal but not 
anti-male' (Daly 1978:28). Daly criticised women who resisted her labelling of males, stating that they imply that their husbands are the exceptions, which she argued, makes these women see themselves as the exception among other women. To Daly, this is a superficial and self-destructive approach and she sees it as one where many women 'hide even from themselves' (Daly 1978:29).

The patriarchal woman is forced to project self-hatred onto herself and she becomes the victim of herself and other women. In their silence, patriarchal women live through men and against those women who feel the need to be free from patriarchal oppression. Daly blames the 'demonic power structures which induce women to internalize false identities' (Daly 1985:49). Women who are content within patriarchal religions 'are leaping over inequalities instead of working through them' (Daly 1985:153).

Patriarchal women work towards their own self-destruction, turning women against themselves and their sisters and ultimately suffocating themselves in the process. Daly states that a patriarchal woman 'sides with her invaders and her possessors' and her 'false selves possesses her genuine Self' (Daly 1978:337). A patriarchal woman:

... turns against her sisters who, themselves invaded and carried into the State of Possession, turn against her Self and against their Selves. The divided ones, the Self-Selves, shelve or sell their Selves. They become ever-hardening shells of their Selves, suffocation their own process. They become iron masks, choking their own becoming, hiding their own know-ing, substituting deception for now-ing. (Daly 1978:337)

The patriarchal woman is timid and is useful to man 'domesticated, harnessed, meek, humble, subdued, cultivated, lacking in spirit, zest, dull, mild and insipid'. These women are 'dedicated to the cult of male divinity' (Daly 1978:344). In Pure lust Daly (1984:193) writes: 'In the society of sadosublimination, pseudo-feminism is also sado-feminism, the father's final solution to the problem of female be-ing.'

Daly comments that women without a sense of self-fulfilment cannot live with the emotion of joy. They become depressed and crave romantic love, marriage, and religion. They seek professional help and turn to alcohol, pills and other manmade substances - Daly (1984:204) describes these types of women as psychically impotent.

Daly later distanced herself from what she called the patriarchal woman, as they did not share her radical vision of women's liberation. I will now continue to examine Daly's perspective on the patriarchal God.

\section{An overview of Daly's patriarchal God}

Daly did not merely challenge the core of Christianity, but also the patriarchal male God. She did not only seek to reinterpret Scripture, but also confronted the very idea of the person of God. Daly saw the image of God the Father, as portrayed in Christian literature, as the embodiment of patriarchy. Daly condemned the patriarchal church for creating the symbol of God the Father in our imagination as a means of oppressing women (Daly 1973:13).

In Daly's works, The church and the second sex (1968) and Beyond God the Father (1973), she describes the Christian church as sexist and as being the basis of all oppressive patriarchal institutions. In her opinion, the church either demonises (e.g. Eve) or idolises (e.g. the Virgin Mary) women. Echoing De Beauvoir's in The second sex, Daly proposes the equality of women in the church, and, influenced by existentialism, she calls for a genderless concept of the divine that would enable a 'human becoming' (Daly 1973:13). In Beyond God the Father Daly declares God as a static, despotic male figure (Daly 1973:13) who was the architect of an oppressive symbolic system. Daly continues to say that patriarchal male language has acted as a 'gang rape on women's bodies and minds' (Daly 1985:152).

Throughout the ages, women only had male role models and one of these is God. Mary Daly wanted to change these concepts.

Daly claims that many people have distorted concepts, images and attitudes towards God, and that the symbols and images used for God grip people's imaginations - something she rejects as primitive and inadequate (Daly 1975:180). Although she states that no theologian or biblical scholar literally believes that God is male, she also states that evidence does exist that the 'absurd idea that God is male lingers on in the mind of theologians, preachers, and simple believers that is not entirely explicit or conscious' (Daly 1975:180). Humans have been subtly conditioned into believing that God is male, and in Daly's opinion this has had an adverse effect on women's self-esteem and identity. For Daly the 'misleading and harmful notion of God' by 'de-hellenizing theologians' with their concept of the divine as 'divine-omnipotence, divine-immutability, and divine-providence' is problematic because the modern man [note her use of man here] finds it alienating (Daly 1975:182). For Daly, the immutability of God is problematic because it reflects an 'all-just God who evidently wills and permits oppressive conditions to exist' (Daly 1975:182). Daly thus suggests that theological awareness concerning the idea of a changeless God must be challenged to avoid evil and oppressive conditions for women. Despite past efforts, 'a picture of God and of man's situation remains paralysing' (Daly 1975:83).

For Daly, God became an inadequate static concept that invites suspicion, and thus she held that God, as Father, ought to die, since she saw this one-sexed symbol of God as problematic and sexist.

Daly holds God responsible for generating god-males and God's divine plan, which, she believes, created sexual stereotyping, and a sense of poor self-worth among women (Daly 1985:13). She sees God in the role of a judge and describes the Trinity as the paradigm of all male processions 
and the Christian God as a 'transsexed caricature of the great Hag herself' (Daly 1978:86). When Daly engaged with the church fathers' views on women and the concept of women's special sinfulness, she states that women's subordination was inscribed in the heavens (Daly 1975:63).

Daly also reminds us that God as a patriarchal Father works to sustain the privileged status of his sons on earth (Daly 1975:180). God is ambivalent - being both loving and jealous (Daly 1985:1). Men externalise and internalise God's image of superiority, and use the images of the patriarchal God as the explanation, judge, and definer of sin. They use this misogynist strategy to maintain in women 'a false consciousness and selfdestructive guilt feelings' (Daly 1985:30-31). For Daly, the image of Jesus as God is no longer helpful to women's selfidentity, as it keeps them locked into their sado-masochistic posture of self-glorification and self-abnegation respectively. To Daly, the androgynous Christ is the 'Supreme Swinging Single ... a unisex model, whose sex is male' (Daly 1978:88). She renamed Christology to Christolatry and argued that as Jesus was used as a scapegoat for the sins of the human race, so too are women the scapegoats for patriarchy as they lack the prestige of being male. Daly rejects the image of Jesus as God and claims it to be redundant. She also refers to Jesus as the foetal patriarchal male who wishes to devour the Goddess and women live (Daly 1978:81).

Daly accuses the Trinity of being totally in unity through their mutual love as expressed by the procession of the third person named the Holy Spirit (Daly 1978:38). The maleness of God, as contested by Daly, alienates women from his image and therefore they cannot identify with God as male. The Trinity becomes a quintessentially homo-erotic procession of male self-absorption and deception. Not only does she accuse the Trinity of putting on a one-act-play as the original love story performed by the Supreme All Male Cast, but also finds them responsible for the rape of the Virgin Mary. In Daly's opinion, Mary was a servant of God, and a 'domesticated goddess' who needed to be liberated from her relationship with Christ - as do all women (Daly 1978:38, 76, 83).

And then there is Daly's fourth paradigm, namely that of the bioiphilic woman as ultimate be-ing.

\section{An overview of Daly's biophilic woman}

Daly's concept of the biophilic woman changed over time as her attitude on patriarchy grows more intense. At first, Daly believes that it is possible for women to gain freedom from patriarchal stereotyping by confronting patriarchy through dialogue between men and women (Daly 1975:136). In an article titled 'The return of the protestant principle' (Daly 1969) she explains that biophilic women will have to be willing to face meaninglessness, will have to be tolerant of ambiguity and will have to accept that there are no fixed answers to ultimate questions. All authorities are imperfect and are not able to provide answers to ultimate questions (Daly 1969:339). As Daly did, biophilic women will have to accept that androgyny is a vacuum that sucks its victim (woman) into itself and that the patriarchal male is not redeemable (Daly 1978:388). Biophilic women, therefore, will have to become part of the sacred space (situated in the mind) to ensure self-actualisation and transcendence (Daly 1972:171-172). In Daly's concept of sisterhood, women must bond with each other and separate themselves from men. Only then will women be able to find their own voices, and begin to name themselves, others, and God.

As Daly's concept of the biophilic women grows more radical, she begins to define it as the liberator for women, a way for them to abandon patriarchal self-alienation (Daly 1979:23).

In order for Daly's biophilic women to participate in Being, she believes that they will have to understand that selftranscendence will enable them to acknowledge that 'all presently envisioned goals, life-styles, symbols, and social structures may be transitory and that they will be free from idolatry, or absolutising, even to their own individual causes (Daly 1978:29). By participating in Be-ing, biophilic women will give up their role as 'the other' without making anyone else 'the other' (Daly 1978:34-40). Women's space is not a place of escapism, but a place where biophilic women are themselves - the moving centre that could possibly move the world (Daly 1978:151).

Biophilic women have to challenge the very misogynist religious teachings, such as the fall, and must reject patriarchal oppression. She warns that the patriarchal oppressors will try to undermine women (Daly 1985:50-51) and that, therefore, biophilic women need to be intolerably deviant (Daly 1985:65). Daly explains that biophilic women are the hated antichrists of patriarchy (Daly 1985:95-97).

Biophilic women must also ask non-questions about nondata, by replacing the grandiose selves of patriarchal males with 'Ludic cerebration thinking out of experience', in order to unlock 'intricacies and ambivalences of the human situation' (Daly 1975:37). 'Ludic cerebration', states Daly, is a 'free play of intuition in our won space, giving rise to thinking that is rigorous, informed, multi-dimensional, independent, creative thought', where biophilic women when they participate in Be-ing can be 'intuiting, reasoning, loving, imagining, making, acting, whilst courage, hope, and play, is part of living' (Daly 1975:49).

However, central to Daly's demand of biophilic women is that they must be aware of patriarchy in all of its manifestations in order to avoid self-sacrificing themselves for the salvation of men (Daly 1978:177-178). Biophilic women have to work at decoding patriarchal language and its myths to avoid further mutilation (Daly 1978:19-20).

Daly explaines that biophilic women are spooking, sparking, and spinning. Through spooking, biophilic women defend themselves against patriarchy in their journey towards wholeness (Daly 1978:321). Sparking binds biophilic women together in sisterhood (Daly 1978:354), and spinning is a 
means through which women create their biophilic selves and a biophilic cosmos (Daly 1978:385).

Daly's biophilic women have to realise that they are the source of their 'own Self-esteem, with high expectations of themselves', who live apart from the sado-society. In their world, they reverse patriarchy and ensure that they never commit violence against other women who may block their creativity (Daly 1978:216, 370).

In order for women to analyse and evaluate their conversion from patriarchy to biophilic health, women have to sense their difference from the patriarchal norm; they will pay a price for their difference; they will have to be womenidentified-women and they will have to remain radical feminists. Being radical feminists, they have to be able to see through, exorcise, and renounce the 'patriarchal god to avoid sliding back into the Sadostate' (Daly 1978:354).

In what follows, I will evaluate Daly's quadripartite theological and philosophical paradigms. It will become evident that Daly's postulations do not take women anywhere meaningful in their struggle against patriarchal oppression, at least not Christian women, but that she has contributed to the further marginalisation of women in her views on God, men, and women.

\section{Questioning Daly's views}

Daly has undoubtedly drawn our attention to many crucial problems that women have encountered within society and indeed within the church.

However, her attack on the Christian God does not solve the humiliation, rejection, subjugations, and pain women suffer under a patriarchal system. Whereas women were the victims of male oppression, Daly's solution to this is to remake God as the villain. Daly's total dismay and discontent with how males treated her sets her on a self-righteous course to rename God. Daly could no longer differentiate between the roles of men and woman and, for her, Christianity became incompatible with feminism.

An analysis of Daly's views on patriarchy does not offer us a working hypothesis regarding women's self-identity in the Image of God. God created women and men for a purpose. Daly inappropriately assigns a singular purpose to the female-form based on women's physical design only. I contend that through Daly's improper assumption that the purpose of women is merely biological, she has functionally reduced them to sexual beings. We find numerous texts in the Bible that deal with the differences between men and women and our different roles. However problematic these texts may be, they do not represent a checklist for stereotyping what each gender should do or not do. Instead, they teach us how to relate to each other in, and through, God.

Daly villainises God and all men and she distances herself from women who did and do not agree with her views. We need to question whether Daly's quadripartite theological and philosophical paradigm has contributed to our understanding of gender issues in Christian theology in any way. In Daly's eyes, Christianity is male; Daly is female, and therefore cannot be a Christian. Her rather narrow views on males, females and God are reminiscent of those held by many of the church fathers about women.

Against this background I will now evaluate her patriarchal male concept.

\section{Patriarchal male}

In her earlier writings, Daly writes highly of feminist men. She also admits that there were men who defended and assisted her both in her professional and personal life. Initially, Daly sees the possibility of a true being and becoming through the healing of conflicts between men and women on a conscious level of the androgynous being and mode of living. The split of feminine and masculine roles for the earlier Daly is a social construct and not a true reflection of individuals (Tyminski 1996:98). The later Daly rejects the term androgyny as a function of the 'fixation on humans' and discards inclusive language.

In her later writings, however, Daly's essentialism goes even further and pushes women into occupying a completely different space from men (Knutsen 1996:171).

Daly would have considered the question 'What about men?' as absurd because, in her method of thinking, she resists the inclusion of men (Grigg 2006:22). Daly merely reduces men to 'evil by nature', thus essentialising men just as she essentialises women (Young 1999:198).

Although Daly dismisses the labelling of other's views of her as essentialist, Jones contends that she is a biological essentialist because of Daly's postulation 'that the source of women's revolutionary way of being rests within them' as part of their embodied distinctiveness (Jones 2000:30). Since there is something ontologically or anthropologically essential about the nature of women that is the same, Daly's argument is a reversal of the sexist argument that explains the origin of male dominion (Jones 2000:182).

Daly has reversed the argument against patriarchy by using the same sexist arguments that those who supported patriarchy are accused of using. Daly is simply using a sexist argument which relies on essentialism. She reverses it, but retains the sexism, homophobia, xenophobia, and racism implicit in a sadosociety in the first place (Rodkey 2008:296).

By devaluing males, Daly does not provide a solution to the gender dilemma that has faced women for centuries. Unfortunately, what Daly ended up contributing to was a greater division in the gender debate. Ruether (2011) contests the following:

Mary Daly concentrates on a passionate disclosing of the inhumanity of males and their culture of rape, genocide, and war. The history of women becomes a trail of crucifixions, with 
males as the evil archons of an anticosmos where women are entrapped. (p. 390)

Daly was naive in her portrayal of women as morally superior beings 'who intrinsically possess creative values superior to any values articulated by men' (Andolsen 1981:293). Daly's approach was 'reversed female chauvinism that could cause one to lose touch with the human face of males' (Ruether 1983:188).

Daly's ontological conclusions about males and females are depersonalising. They entail the reversal of sex-types and fail to overcome the dichotomy of sex-role stereotyping. By turning men into scapegoats and by 'castrating' them she makes another the Other (Fiorenza 1975:117-118). Whereas patriarchy postulated women's evilness and defectiveness, Daly does the exact opposite when she postulates that men are evil and defective.

In decoding Daly's views on the patriarchal male, we can ask whether Daly was a man-hater, or whether she simply withdrew from the battle of the sexes, leaving men to fend for themselves. This is a question that will always linger in one's mind whenever Daly's name is mentioned. As Daly becomes more radical in her views, she becomes increasingly outspoken against women who did not live up to her standards of what constitutes feminism. In the following section, I will analyse Daly's attitude towards the women she labels patriarchal females.

\section{Patriarchal female}

It is clear that Daly has separated and marginalised those women whose different points of view did not support hers through her labelling of them as patriarchal women.

At this stage, it is important to point to Daly's utopian, gynocentric lesbian separatism. I concur with Tyminski (1996:66) who states that Daly's lesbianism is the paradigm for female sexuality insofar as it signals an overcoming of the unnatural separation of women from their archetypal and collective selves. In her opinion, women who have not achieved this reunion are merely token women whose minds are still controlled by pallocracy (Daly 1978:382-383). Daly blames women like this for pathetically attempting to mimic role-playing into the phallic fixation factories of snooldom, seeking the excitement of bored boys.

Women, heterosexual or lesbian, whose consciousness have been destroyed, may exercise free speech, but may not describe themselves as feminist and may not speak on behalf of feminists (Daly 1984:66). Women who require safety, shelter, rules, form, and love are playing in a 'chic contemporary style', and are expressing self-hate and horizontal violence. These women are on a path to self-destruction and Daly names this self-destruction masosadism. Women who appear to be feminists are actually detrimental to feminism; it is man-made, a delusion, and not sexual liberation (Daly 1984:64). These women are on a self-destructive path (Daly
1984:109) and have a false sense of their selves that originated in a belief that males protect them (Daly 1984:142). Women who do not radically break with patriarchy are not aware of their own suffering and become torturers of their and other women's identities (Daly 1984:170).

Daly's utopian, gynocentric lesbian separatism, which excludes the patriarchal female, rests on shaky ground. Again, her essentialism is clear. Daly's preoccupation in defining female sensibility points to her dangerously erroneous generalisation of women, following the mode of her case against men. The formation of women's self-identity is not only constructed by being aware of patriarchy, but also is innate and socially constructed by different norms and people in the process of forming self-identify. Raymond (1983) argues:

Yet there are differences, [among women] and some feminists have come to realize that those differences are important whether they spiral from socialization, from biology, or from the total history of existing as a woman in a patriarchal society. (p. 17)

The only real difference that can change a person's 'ontological placement on Daly's dichotomous map' (Alcoff 1998:6) is the difference that exists in sexuality, in which Daly excludes males and those women who do not share in her utopian gynocentric lesbian separatism. We must reject Daly's views on women as patriarchal females. I have explicated Daly's distain of patriarch as a concept, and her rejection of women who she perceives to be supportive of this. Daly's anger, though, is always directed chiefly at God, who in her opinion was the worst patriarch of all.

\section{Patriarchal God}

Daly's theology is, according to her critics, bifurcating and polarising to such an extent that it is not useful in constructive theological and philosophical debates (Friedman 1998:70). Furthermore, it is too skimpy to be accurately assessed (Fulkerson 1991:662). Daly's conversations are too far out of the Christian tradition and have to be rejected because they are too difficult to enter into or engage with effectively (Grigg 2006:20-22). Kassian (1992:203) states that Daly's definition of God 'contains such expletive language' that she considered it 'inappropriate to repeat it'.

Dale originally criticised language that refers to God in male terminology. Daly later concludes that people's perceptions about God were so grounded in physically, spiritually and culturally patriarchal views that it had become pointless to persist in any argument against God's maleness.

Although I agree with Daly's views on the inadequacy of language, I do not find the way in which she reworked the gender of God and the renaming of Him at all helpful. I concur with Groothuis (1997), who offers us a good explanation about the sexuality of God when she writes:

Nowhere in the Bible is God referred to as a sexual being. Rather, especially in Old Testament Law, sexuality is kept meticulously separate from religious worship and other spiritual concerns. 
Completely absent from biblical religion is any hint of sexuality as a spiritual force, or of masculinity and femininity as spiritual principles in the God-head of the cosmos. Biblical religion stands distinct and apart from the pagan fertility religions in it's strictly nonsexualized concept of spiritual reality and the nature of God. The nations surrounding ancient Israel believed that the fertility deities created and perpetuated human, plant, and animal life through their own divine sexual activity. But Israel did not share in the divinization of sex; it was a phenomenon of the creature, not of the deity. (p. 101)

God cannot merely be dismissed as an androgynous being who was invented by men who sought power in their own masculinity. Neither can the many wrongs bestowed upon women through men identifying with God's maleness be defended.

Daly was chiefly concerned about the language the church uses to describe God. She believed that women would only find themselves when they discovered God as a personal experience of wholeness and meaning, rather than as a static entity. Daly discarded God and expected women to follow suit. Women should not attack the patriarchal God but rather leave him behind. That is exactly what Daly did, and she set herself on a quest to rename God. In order to rename God, Daly believed that women have to reach inward towards the God beyond and beneath the gods who have stolen their identity. In renaming God, Daly proposed that God is a verb and not a noun. Daly felt strongly that the right to name is central to women's experience of religion.

Daly believed that women could only gain spiritual liberation once masculine terms for God were removed from Scripture and theology. Therefore, Daly advanced her argument for a process theology in the naming of God the Verb; in hearing and naming ourselves out of the depth, women are naming towards God, which is what theology has always been about (Schaab 2001:1).

It is clear both that Daly built her theology around patriarchy in religion and that she launched an assault on a completely male-dominated society. Daly blamed women's problems not only on religious patriarchy, but sought to reform the church's language about God and to revise the idea of God. Daly's feminist ideology, however, is presupposed and overrides the overt teachings of Scripture, so that her positions cannot be said to derive from the actual interpretation of Scripture itself (Köstenberger 2008:42).

Daly wanted to rename God and to develop new ways of interpreting the Bible. In doing so, however, she was quick to inflate what did not fit her theology and political agenda. Patriarchy, she charged, was an omnipresent and insidious social system that sustained itself and squashed dissent (Jenkins 1997:194).

Patriarchy is responsible for the symbol of God as Father and as a mechanism for keeping women in an oppressive state (Daly 1973:13). According to Köstenberger (2008) Daly, therefore:

desired to mount a challenge to the patriarchal religion of Christianity, a spiritual revolution in which the old order of sexism would be overthrown and a 'new-being' would manifest in women. (p. 41)

The misappropriated metaphorical language she used to replace her notion of a patriarchal God is just as ambiguous as her claim that patriarchal metaphorical language is used for God. Within Daly's concept of a patriarchal god lies history, religion, politics, and ideologies, but the same is true for her unstructured use of myths to replace the patriarchal god. Daly was not interested in replacing God with the Goddess concept, but rather wanted to erase the idea of God as a Supreme Being, One who controls the world and Who keeps human beings, especially woman, dependent and subjugated.

Daly's self-appointed task, the renaming and reifying of God, changes her concept of God from that of 'Supreme Being' to a 'state of Be-ing' and as a 'Verb' for women 'to journey beyond patriarchal fixation' (Daly 1985:xvii).

In typicalDalyian fashion, she tells us what God is like, and how she tells us remains questionable because she has distanced herself from the Christian faith. Her metaphors and myths are insufficient to express the complexity of God's nature, regardless of the fact that she believes that she has a better description of religious reality than that which Christianity has to offer women. Daly's metaphors for God are rooted in existentialism and neo-pagan religious philosophy. She uses metaphors to speak to women's religious experience and as a theological tool to shape her own reality and ideas about God and Christianity as man-made myths. Daly redefines negative metaphors used for women, such as witches, gorgons, nags, hags, and crones into 'positive metaphors for her system' (Daly 1984:387). Again, she pirates from Alice Walker's book, The colour purple, wherein Shug Avery describes God as it. It for Daly, however, is the ultimate reality for women and all elemental creatures (Daly 1984:86-87). Netland (1991) makes the following remark on linguistic absurdities:

Any epistemologically acceptable theory of religious truth must recognize that beliefs are integral to religion and that truth in religion, just as in other domains, must include the notion of propositional and exclusive truth. (p. 150)

This remark is a valid point when one analyses Daly's language for God. I agree with Bloesch, who questions the purpose of metaphors for God-language. He questions whether the purpose of such God-language is to 'give a true knowledge or merely a symbolic awareness of the ultimate reality we call God' (Bloesch 1985:13). Daly was aware that ultimate reality, as envisioned in goals, lifestyles, symbols, and societal structures may be transitory. She thus builds a linguistic theory 'concerned with the finiteness of language and its limitations in describing God' (Daly 1985:28-29). Talbert-Wettler (1995:85) states that Daly's religious language 
conforms God into an object that limits Him in time and space. Daly could not expect her audience to understand the different concepts of God in her promotion of metaphorical language and the ever-changing metaphors she used in the context of women's experiences. Not even Daly can evade the descriptive limitations of language.

In Daly's attempts at changing metaphors she obscured the fact that human language will always objectify, quantify and limit our understanding. Such feminists arbitrarily rejected propositional god-language in favour of metaphorical language. On what basis did these feminists decide that god-language cannot be both metaphorical and propositional? Human language is limited, but does this necessarily mean that language cannot reveal truth? (Talbert-Wettler 1995:85)

Daly was actually doing what she accused patriarchy of doing. The literal understanding of the maleness of God was, and still is today, abused in patriarchal societies to subordinate women. The views on God being male are, however, not generally accepted today. Daly criticised the literal misuse of the maleness of God through patriarchy, but she remains captive of this literal understanding and cannot escape from it herself. Whereas patriarchy limited God in a metaphor of maleness, she limited God in metaphorical language. As such God becomes a loveless impersonal being, which is a reversal of the biblical message.

\section{Biophilic women}

Daly's view of sexism as the root of patriarchal evil and her dismissal of others evokes concerns, especially through her creation of the biophilic woman. Daly's biophilic women are wild women living in the transcendent now and are inherently different from both the patriarchal male and the patriarchal female in that they completely reject a patriarchal God. In her view, liberation for women is primarily spiritual; they 'discover an alternative land within their inner selves', and in this alternative land 'they learn to communicate with new language', breaking from old patriarchal language and transforming theirs into the dominant language (Ruether 1983:30).

These biophilic women live in a healthy background within the bonding of sisterhood, wherein they prioritise women's experience in order to heal and to discover the lost self. Living in this background enables biophilic women to withdraw their energies from patriarchy.

We can argue that for Daly's biophilic women, living in the background is indicative of what she believed it would mean to live in a physical world through imagination. One can also argue that we are all inclined to some extent to live through our imaginations, for it is through our imagination that we can escape the harsh realities we face on a daily basis. Nevertheless, for Daly, the biophilic women living in the background was a reality - a healthy choice and an effective ethical and political choice that excluded men and women who do not form part of her vision. Daly's post-Christian reality is a gradual process. Firstly, she indicates that the church had entered a new era in an article, 'Dispensing with Trivia' (1968). Secondly, she focuses on women as 'An exodus community' (1972). Thirdly, her book, Beyond God the Father (1985) promotes the full blossoming of Daly's post-Christian reality.

Durham (1997), in her psychological analysis of Daly, states:

The villainized male is the despised self; the Biophilic woman is the idealized self; the Background is the magic circle; the Journey is the escape to the magic circle; the ethical shoulds are the tyranny of the shoulds. The dismissal of the views of others is an aggressive-vindictive strategy for putting conflicts out of action. Citing hatred of women as the sole cause of the problem between the sexes can also be considered a strategy for putting conflicts out of actions through failure to take one's share of the blame. (p. 181)

Daly's ideology of pure biophilic women separates patriarchal women as non-beings and causes unnecessary dichotomy among women (Fiorenza 1983:24-26).

Daly reversed androgyny to a gynocentric ideal wherein the mutuality between the sexes is destroyed. Daly faults all males, whereas she sees the biophilic woman as a being without fault.

Placing the necrophiliac male outside the epistemologically privileged position of biophilic women is philosophically, historically, and socially indefensible (Davaney 1987:31-49). Daly made a dire mistake by placing all of her confidence in her own intuition without consulting external references, and so do her biophilic women (Allen 1976:67-72).

Daly's self-exaltation, self-righteousness and superiority, as well as that of biophilic women, invoked and invited animosity between the sexes, not reconciliation. Daly is guilty of remaking God in the image of the victim - God becomes the champion of Daly's messianic, history-bearing biophilic women and she consigns men to hell, while Daly's biophilic women become the idealised, heroic superwomen (Brayn 1976:50-55).

In Daly's creating of the biophilic women, and their participating-in-Be-ing, she managed to mould a form of 'suprasexual existence of self-independence, self-sufficiency, and self-integral unity' (Tong 1978:41) from which she excluded all others.

To identify with biophilic women's experience as the ultimate experience is not possible because experience can also have some ambiguous and ambivalent qualities that can be passed up as reality. Therefore, Daly's description of biophilic women as infinite movement, as good, true and revelatory is as guilty of idolatry as it is inadequate, because it limits women's (and men's) experience (Stenger 1987:473-474). 
Daly has reimprisoned women conceptually, and according to Hewitt (1995):

Daly's glorification of female attributes and values mobilizes identity thinking within the walls or rigid conceptualizations that foreclose on the mystery of individual being in all its diversity and difference. (p. 199)

Daly merely reversed the patriarchal glorification of the male to the ultimate glorification of the biophilic woman something that is clearly reserved for a chosen few.

Daly created an exclusive lesbian community in her background that has little to do with real historic women. She became imprisoned by her own gynocentric language which points to her ultimate failure and inability to deal with the real world with its real problems and ultimately with women's struggle against patriarchy.

Daly's vision of her self-created biophilic women is otherworldly, a denial and an escape from the patriarchal world, and a place wherein only a select few are welcome. Daly, with her creation of biophilic women living in the background, turned her back on women's struggle against patriarchy.

\section{Closing remarks}

The existence of patriarchy has had a major impact on people's self-identity over thousands of years. It is true that society and culture, and the way they function, have conditioned the self-identity of women and men through 'un/spoken, un/acknowledged and un/conscious' conditions and rules (Sundberg 2008:52).

Daly argued that the fact that God is presented through masculine terms and symbols has different implications for men and women. The masculine representation of God proposes no problem to males, whereas women may feel alienated from the Image of God. The maleness of God, as reflected throughout history, has had a profound effect on some women's self-identity. These women find it difficult to identify with a male God as they feel that, since they have not been created in the Image of God, they are denied full humanity. Not only have women been excluded from the Image of God, they have also been denied creative expression. Historically, women had been excluded from participating in public and private spheres, which naturally included the church.

Some women find it difficult to relate to masculine terms for naming God, such as the God of Israel, the Father of Jesus, and the Father of all believers. The idea of God as a patriarch affects society, the individual believer, and impacts on our perceptions of gender. The impact of religious identity is 'widely recognized as important in creating cultural communities, which in turn directly influence their adherent's attitudes and behaviour toward gender roles in society' (Keysar \& Kosmin 1995:49).

For Daly, patriarchal views on women as being inferior had dire consequences, including that women find it difficult to identify with God and men. Women have been labelled many things: defective and misbegotten, sick she-asses, hideous tapeworms, the posts to hell, the most savage of beasts, full of lust, the origin of sin through Eve, mere helpmates to men, not created in the image of God, inferior, and as only good for procreation. For many women, these hurtful and derogatory descriptions lead them to question both God and whether they could bear this dominant image of God.

Both women and men find our identity, and that of God, in the images and symbols of God. We use language, metaphors and symbols to articulate our experience, self-identity, and views on God, ourselves, and the world at large. Language and symbols, however, can restrict our ability to speak about God.

On a personal note, and with specific reference to the gender of God, I question whether we indeed can speak about God in gender terms. Whilst Daly argues that male language inseparably links male dominance and God, I contest this. When we speak of the fatherhood of God, we are using symbolism and I believe that this does not include or imply women's subordination. God's supposed maleness should, on the contrary, never permit, nor legitimise the oppression and subordination of women. The term God implies a being without a human body, Who is neither male nor female. Whilst feminists claim that male metaphors legitimise the exclusion of women's self-identity and experience of God, the opposite can also be true - female metaphors such as the Goddess legitimise the exclusion of men's self-identity and their experience of God.

In conclusion, I concur with Heyward (1979:71-72) that Daly was 'spinning off into her own space of female idolatry and isolation', and that she is someone who burns bridges, traumatises and pulls life lines in, and then 'flees inward, for a personal exorcism of the mind'.

The aim of this article was to evaluate the four main players in Daly's quadripartite patriarchal theological and philosophical paradigm, namely the patriarchal male, the patriarchal female, the patriarchal God and the biophilic woman. I contend that we can hardly accept that it is possible to engage with Daly in the further development of Christian teaching in a meaningful and constructive manner since Daly wrote and focused mainly on the Daly-story.

\section{Acknowledgements Competing interests}

The author declares that she has no financial or personal relationships which may have inappropriately influenced her in writing this article.

\section{References}

Alcoff, L., 1998, 'Cultural feminism versus post-structuralism: The identity crisis in feminist theory', Signs 13(3), 405-436. http://dx.doi.org/10.1086/494426

Allen, C., 1976, 'Self-creation and loss of self: Mary Daly and St. Teresa of Avila', Religious Studies 6(1), 67-72. 
Andolsen, B.H., 1981, 'Racism in the nineteenth and twentieth century Women's Movement: An ethical appraisal', PhD thesis, Faculty of Theology, Vanderbilt College, Nashville, TN.

Bickley, J.E., 2011, 'The relationship between second-wave feminist philosophy and interpretation of biblical gender roles by entering seminary students', PhD thesis, Faculty of Theology, The Southern Baptist Theological Seminary, Louisville, KY.

Bloesch, D., 1985, The battle for the Trinity: The debate over inclusive God-language, Servant, Ann Arbor, MI.

Brayn, G.M., 1976, 'Does feminist theology liberate?', -Foundation 19(Jan.-Mar.) 50-55.

Bridle, D., 1999, 'No man's land: An interview with Mary Daly', What is Enlightenment Magazine, 16, Fall-Winter, viewed 27 October 2011, from http://www. enlightennext.org/magazine/j16/daly.asp

Daly, M., 1968, The church and the second sex, Harper \& Row, New York, NY.

Daly, M., 1969, 'Return of the protestant principle', Commonweal 90, 338-341.

Daly, M., 1972, 'The spiritual revolution: Women's liberation as theological re-education', Andover Newton Quarterly 12(4), 163-176.

Daly, M., 1973, Beyond God the father: Toward a philosophy of women's liberation, Beacon, Boston, MA

Daly, M., 1975, The church and the second sex, rev. edn., Harper \& Row, New York, NY.

Daly, M., 1978, Gyn/ecology: The metaethics of radical feminism, Beacon, Boston, MA.

Daly, M., 1984, Pure lust: Elemental feminist philosophy, Beacon, Boston, MA.

Daly, M., 1985. Beyond God the father: Towards a philosophy of women's liberation with an original introduction by the author, Beacon, Boston, MA.

Daly, M., 1987, Websters' first new intergalactic wickedary of the English language, conjured by Mary Daly in cahoots with Jane Caputi, Beacon, Boston, MA.

Davaney, S., 1987, 'The limits of the appeal to women's experience', in C.W. Atkinson, C.H. Buchanan \& M. Miles (eds.), Shaping new vision: Gender and value in American culture, pp. 31-49, UMI Research Press, Ann Arbor, MI.

Durham, P.H., 1997, 'Patriarchy and self-hate: Mary Daly's assessment of patriarchal religion appraised and evaluated in the context of Karen Horney's psychoanalytic theory', DPhil thesis, School of Graduate Studies, University of Ottawa, Ottawa.

Fiorenza, E.S., 1975, 'Why not a category of friend/friendship?' Horizons 2, 117-118.

Fiorenza, E.S., 1983, In memory of her: A feminist theological reconstruction of Christian origins, Crossroad, New York, NY.

Friedman, S., 1998, Mappings: Feminism and the cultural geographies of encounter, Princeton University Press, Princeton, NJ. http://dx.doi. org/10.1515/9781400822577

Fulkerson, M., 1991, 'Sexism as original sin', Journal of the American Academy of Religion 59(4), 653-675. http://dx.doi.org/10.1093/jaarel/LIX.4.653

Grigg, R., 2006, Gods after God: An introduction to contemporary radical theologies, State University of New York Press, New York, NY.

Groothuis, R.M., 1997, Good news for women: A biblical picture of gender equality, Baker Books, Grand Rapids, MI.

Hewitt, M.A., 1995, Critical theory of religion: A feminist analysis, Fortress, Minneapolis, MN
Heyward, C., 1979, 'Speaking and sparking, building and burning', Christianity and crises $39,66-72$

Jenkins, T.E., 1997, The character of God: Recovering the lost literary power of American Protestantism, Oxford University Press, New York, NY.

Jones, S., 2000, Feminist theories and Christian theology: Cartographies of grace, Fortress, Minneapolis, MN.

Kassian, M.A., 1992, The feminist gospel: The movement to unite feminism with the church, Crossway Books, Wheaton, IL.

Keysar, A. \& Kosmin, B.A., 1995, 'The impact of religious identification in educational attainment among American women in 1990', Journal for Scientific Study of Religion 34(1), 49-62. http://dx.doi.org/10.2307/1386522

Knutsen, M., 1996, 'Beyond God the Father - Towards a trinitarian theology of the cross: The challenge of Mary Daly and resources in the works of Jürgen Habermas and Paul Ricoeur for contemporary Christian theology', 2 vols., PhD thesis, Faculty of Theology, University of Chigago, Chicago, IL.

Köstenberger, M.E., 2008, Jesus and the feminists: Who do they say that He is?, Crossway Books, Wheaton, IL.

Netland, H.A., 1991, Dissonant voices: Religious pluralism and the question of truth Eerdmans, Grand Rapids, MI.

Raymond, J.G., 1983, Contemporary feminist thought, Hall, Boston, MA.

Rodkey, C.D., 2008, 'In the horizon of the infinite: Paul Tillich and the dialectic of the sacred', PhD thesis, Faculty of Theology, Drew University, Madison, NJ.

Ruether, R.R., 1983, Sexism and God-talk: Toward a feminist theology, Beacon, Boston, MA.

Ruether, R.R., 2011, 'The new earth: Socioeconomic redemption from sexism', in W.T. Cavanaugh, J.W. Bailey \& C. Hovey (eds.), An Eerdmans reader in contemporary political theology, pp. 377-393, Eerdmans, Grand Rapids, ML.

Schaab, G.L., 2001, 'Feminist theological methodology: Toward a kaleidoscopic model', Theological Studies 62(2), 341-365. http://dx.doi.org/10.1177/ 004056390106200206

Stenger, M.A., 1987, 'Male over female or female over male: A critique of idolatry', Soundings: An Interdisciplinary Journal 66(4), 464-477.

Sundberg, D., 2008, 'Exploring the consequences of perceptions of the divine, and the church, in the making of self-identify: A case study of congregants from Roman Catholic and charismatic communities in East London, South Africa', MA dissertation, Faculty of Sociology of Religion, Rhodes University, Grahamstown.

Talbert-Wettler, B., 1995, 'Secular feminist religious metaphor and Christianity', Journal of the Evangelical Theological Society 38(1), 77-92.

Tong, K.K., 1978, 'The sex of God: A critique of Mary Daly's transcendental theology for women's liberation', in J.H. Grace (ed.), God, sex and the social project, pp. 39-50, Edwin Mellin, Toronto.

Tyminski, R., 1996, 'Divinity, transcendence and female subjectivity in the works of Mary Daly', PhD thesis, Faculty of Theology, Centre for the Study of Religion, University of Toronto, Toronto.

Wood, J.M., 2013, 'Patriarchy, feminism and Mary Daly: A systematic theological enquiry into Daly's engagement with gender issues in Christian theology', DTh thesis, College of Human Sciences, University of South Africa, Pretoria.

Young, K.J., 1999, 'Rejoiner to Rita. M. Gross', Journal of the American Academy of Religion 67(1), 195-198. http://dx.doi.org/10.1093/jaarel/67.1.195 